\title{
INTENSIFICATION OF INVESTMENT IN THE RENOVATION OF RESIDENTIAL REAL ESTATE IN THE CONTEXT OF THE SUSTAINABLE DEVELOPMENT GOALS
}

\author{
Svitlana Kovalivska ${ }^{1}$, Andrii Shcherbyna ${ }^{2}$, Vsevolod Nikolaiev ${ }^{3}$
}

\begin{abstract}
The subject of the paper $\epsilon$ is to study the mechanisms for investing in residential renovation in the context of the Sustainable Development Goals. At the same time, sustainable development is considered both from the point of view of safety and environmental friendliness of residential buildings, and from the social point of view of providing housing to citizens from strategic perspective. It is shown that the current sustainable development goals, the definition of indicators of their achievement do not cover the problem of housing deterioration, which is one of the most acute for national and social security, as well as the financial stability of the state. Therefore, the achievement of SDG-11 in Ukraine is in a high risk zone given the catastrophic state of housing, the scale of the problem, and the high cost of its renovation for insolvent households; this does not solve the problem only at the expense of homeowners as follows from the essence and functions of property owners. The situation in Ukraine differs from European countries in that the state is impossible to further subsidize the owners on a large scale. This requires a combination of public investment in renovation of residential real estate with property reform, transforming part of the housing stock into social housing. As the implementation of housing projects concerns the local level, the general shortcomings of strategic management are shown, where there is no vision of communities to solve the problem. Methodology. Based on the methodological developments of the authors on the insolvency of homeowners in Ukraine (A. Shcherbyna), criticism of unjustified approaches to co-financing by residents and local authorities of renovation projects in Kyiv (O. Popeko), and the need to justify and evaluate investment projects to achieve sustainable development goals (S. Kovalivska), the article forms a comprehensive approach to solving the problem in terms of all three aspects. Therefore, the purpose of the paper is to deepen the formulation and analysis of methods to achieve Sustainable Development Goal 11 "Make cities and human settlements inclusive, safe, resilient and sustainable" with the help of provisions on sustainable housing for citizens based on a projectoriented approach and mechanisms for financing projects using public-private partnerships of homeowners with local authorities, as well as taking into account sustainable development goals. Practical implications. The main directions of further progress in reforming property relations in the housing sector and creating tools for intensifying partnership mechanisms at the vertical and horizontal levels in the public administration system are identified. Results. The proposed methodology provides for the selection of projects for budget support and development of recommendations for their implementation, taking into account SDG in several stages: preselection based on cost-benefit analysis; assessment of the impact of the project on SDG (determination of the SDG identity of the project based on a quantitative assessment of the impact of its objectives on SDG and vice versa); determination of the volume and type of budget support (rating of projects based on a comprehensive analysis of their commercial, budgetary and social efficiency, adjusted for the level of manufacturability, export orientation, and SDG identity); development of recommendations for project implementation, which take into account the approaches to assessing the impact of the project on SDG and, conversely, the achievement of SDGs or the risks of
\end{abstract}

\footnotetext{
Corresponding author:

${ }^{1}$ National Institute for Strategic Studies, Ukraine.

E-mail: vkovalivska@gmail.com

ORCID: https://orcid.org/0000-0001-8919-075X

ResearcherID: ABH-3699-2020

${ }^{2}$ Municipal Concern “Centre of Municipal Service”, Ukraine.

E-mail: a.a.shcherbina@gmail.com

ORCID: https://orcid.org/0000-0001-8744-3418

ResearcherID: AAA-6409-2021

${ }^{3}$ Kiev National University of Construction and Architecture, Ukraine.

E-mail: vsevolod.nikolaiev@gmail.com

ORCID: https://orcid.org/0000-0003-0014-1340

ResearcherID: AAB-3328-2021
} 
Vol. 6, No. 5, 2020

their failure to achieve project objectives (4). Value. To link SDG with budget planning, it is proposed to introduce an additional classification of budget expenditures on SDG, which will help to reconcile strategic and budget planning with investment in order to achieve SDG, including in the process of ensuring state participation in programs and projects for renovation and construction of housing based on the concept of sustainable development.

Key words: sustainable development goals, housing, property, public-private partnership, investments, projects, criteria.

JEL Classification: Q01, O20, P41

\section{Introduction}

Occupying high starting positions for achieving the sustainable development goals (SDGs) in the first third of the rating of the Global Index of SDG (Sachs, Fuller, Kroll, Lafortune, Schmidt-Traub \& Woelm, 2020), Ukraine has fallen from 39 to 47 th place over the past 3 years. In 2020, the indicators of the Goal 11 (SDG-11) "Make cities and human settlements inclusive, safe, resilient and sustainable", have shown significant negative trends; this opposes the fact that a large-scale reform of local self-government and territorial organization of power - the reform of decentralization - is considered to be the most successful reform in the last five years in Ukraine (Shevchenko, Romanova, Zhalilo, 2020).

At the global level and in Ukraine, SDG-11 is measured by various indicators (Table 1 shows national indicators).

The State Statistics Service of Ukraine (2020) assesses the progress of achieving SDG-11 according to some available indicators, which are currently measured at the national level (Figure 1).

Table 1

Tasks and indicators of SDG-11 for Ukraine

\begin{tabular}{|c|c|}
\hline $\begin{array}{c}\text { Tasks of SDG-11 } \ll \text { Sustainable development } \\
\text { of communities» }\end{array}$ & SDG-11 indicators \\
\hline \multirow{4}{*}{ 11.1 To ensure housing affordability } & $\begin{array}{l}\text { 11.1.1. Borrower's solvency ratio, PTI (payment-income ratio of monthly expenses of the } \\
\text { borrower and his or her family members to service the mortgage loan debt and the total } \\
\text { monthly income) }\end{array}$ \\
\hline & $\begin{array}{l}\text { 11.1.2. The share of refusals to mortgage borrowers in the total volume of requests for } \\
\text { loans with a mismatch of the solvency ratio (PTI> } 43 \%)\end{array}$ \\
\hline & $\begin{array}{l}\text { 11.2 To ensure the development of settlements and territories exclusively on the basis of } \\
\text { integrated planning and management with the participation of the community }\end{array}$ \\
\hline & $\begin{array}{l}\text { 11.2.1. Proportion of regions that have approved and implemented regional development } \\
\text { strategies and action plans for their implementation created with participation of the } \\
\text { community, \% }\end{array}$ \\
\hline \multirow{3}{*}{$\begin{array}{l}11.3 \text { To ensure the preservation of cultural and } \\
\text { natural heritage with the involvement of the } \\
\text { private sector }\end{array}$} & $\begin{array}{l}\text { 11.3.1. Number of cultural and natural heritage sites included in the UNESCO World } \\
\text { Heritage List, units }\end{array}$ \\
\hline & $\begin{array}{l}\text { 11.3.2. Number of monuments of national importance included in the State Register of } \\
\text { Immovable Landmarks of Ukraine, units }\end{array}$ \\
\hline & 11.3.3. Area of nature reserve fund of national importance, $\%$ of the country's territory \\
\hline \multirow{4}{*}{$\begin{array}{l}11.5 \text { To reduce the negative impact } \\
\text { of pollutants, including on the urban } \\
\text { environment, in particular through the use of } \\
\text { innovative technologies }\end{array}$} & 11.5.1. Volume of air pollutant emissions, \% to the level of 2015 \\
\hline & $\begin{array}{l}\text { 11.5.2. Total emissions of pollutants into the atmosphere from stationary sources, } \\
\text { conditionally reduced to carbon monoxide, taking into account the relative aggressiveness } \\
\text { of major pollutants, \% to the level of } 2015\end{array}$ \\
\hline & $\begin{array}{l}\text { 11.5.3. Total emissions of pollutants into the atmosphere from mobile sources, } \\
\text { conditionally reduced to carbon monoxide, taking into account the relative aggressiveness } \\
\text { of major pollutants, \% to the level of } 2015\end{array}$ \\
\hline & $\begin{array}{l}\text { 11.5.4. Number of cities, in which the average daily concentrations of major pollutants in } \\
\text { the air exceed the average daily maximum allowable concentrations, units }\end{array}$ \\
\hline $\begin{array}{l}11.6 \text { To ensure the development and } \\
\text { implementation of local development } \\
\text { strategies aimed at economic growth, job } \\
\text { creation, tourism development, recreation, } \\
\text { local culture, and production of local products }\end{array}$ & $\begin{array}{l}\text { 11.6.1. Number of jobs in the field of tourism (average number of full-time employees of } \\
\text { collective accommodation and tourism entities of Ukraine), thousand units }\end{array}$ \\
\hline
\end{tabular}

Source: Sustainable Development Goals: Ukraine. National report (The Ministry of Economic Development and Trade of Ukraine, 2017) 


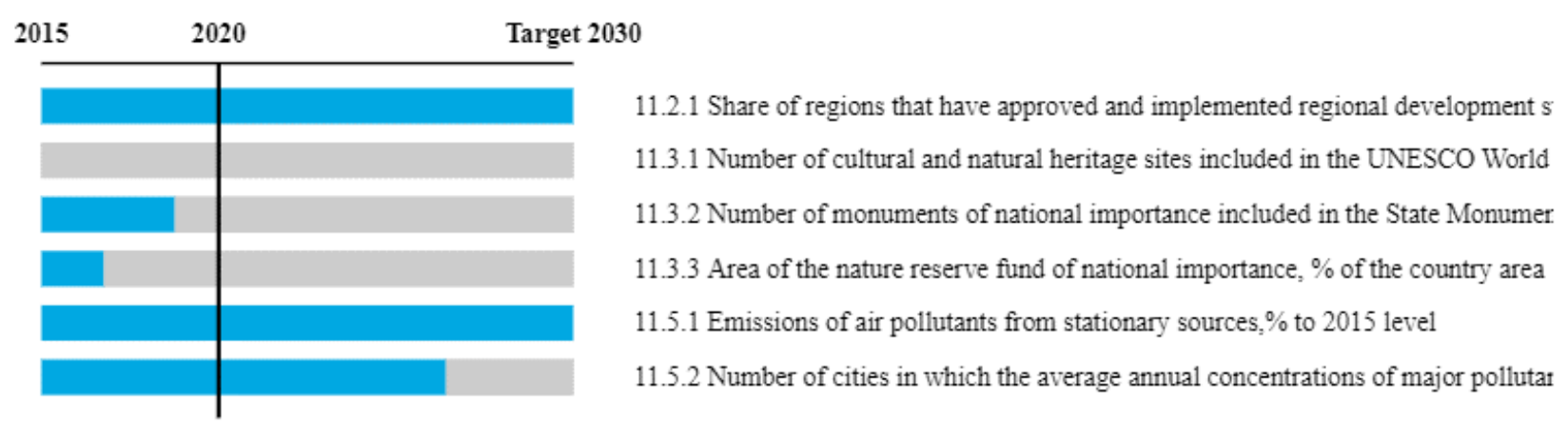

Figure 1. Assessment of progress in achieving SDG-11 in Ukraine

Source: State Statistics Service of Ukraine (2020)

This indicates that the situation in Ukraine is not monitored with the consistency of domestic statistics with the international indicators and that Ukraine's place in the international ranking may be overestimated. We also believe that the implementation of SDG-11, as one that localizes the goals and objectives of the Agenda-2030, requires in-depth analysis.

The specificity of Ukraine determines the attention primarily to domestic research and publications of authors from near abroad. Among Ukrainian scientists, the works of I. Mantsurov (Shevchuk, Kovalchuk, Malisheva, Mantsurov, 2014), A. Maksyuta, V. Nikolaev (Maksiuta, Kovalivska, Nikolaiev et al., 2017), V. Shevchuk (2006), and others.

Along with the macroeconomic approach, the scientific literature considers the sectoral approach to the implementation of SDG-11 in construction. Accordingly, O. Belenkova (2020) notes that the world and domestic experience of implementing elements of sustainable development in construction management processes is not systemic, as researchers focus on the implementation of general social or environmental conditions during construction. The concept of sustainable development of construction should be much broader and cover, on the one hand, the formation of stakeholders in construction projects, environmental and social requirements for construction products, and on the other hand, the formation of networking culture based on sustainable development, environmental management, environmental protection and social responsibility for the participants of the investment construction process. However, if these requirements contradict the profitability of enterprises, their implementation in practice will remain purely declarative. This is happening today in construction because construction companies are not represented at all among Ukrainian participants in the UN Global Compact to ensure sustainable development.

O. Belenkova formulates a number of principles:

- The principle of balanced economy and ecology requires significant changes in technology, materials, machines, and mechanisms used. Of course, this principle must be maintained not only in the process of production and commercial activities its implementation extends to buildings, structures, premises, communications, and landscaping of the surrounding area. The latter is achieved exclusively by construction companies only if they have proper property status;

- The principles of balance of economic and social spheres is realized due to the proper speed of construction. The latter becomes possible when the contractors have the appropriate material and technical base. At the same time, the financial stability of construction contractors should provide an opportunity to carry out economic activities throughout the long construction cycle. After all, the bankruptcy of development companies, developers, and contractors is one of the main reasons for delaying the commissioning of facilities, or the emergence of unfinished projects.

The financial stability of construction companies directly determines the possibility of implementing the third principle, which is the most important, from our point of view: ensuring development with no harm to future generations. As this principle is focused on the long term, it "imposes responsibility" on construction companies for design decisions and efficient real estate management.

In our opinion, SDG-11 is achieved in three processes: design, construction, and operation of facilities. This approach is developed in collective monographs on real estate management by V. Nikolaev (Kuybida, Nikolaiev, Nikolaieva, 2017), T. Nikolaeva (2018), N. Siniak (2015), S. Shavrov, and others (Voitov et al., 2018). Particular attention is paid to the use of digital technologies, namely, building information modelling (BIM) (Kuybida, Nikolaiev, Nikolaieva, Sichny et al., 2018).

One example of cooperation to achieve common sustainable development goals is to solve the problems of housing at the national and regional levels, taking into account the high level of wear and tear, high cost of total renovation, and unavailability of funds.

In addition to assessing the relationship between SDG-11 and real estate lifecycle management, 
housing policy and housing management emphasize the critical condition of residential real estate, which poses a specific threat to the sustainable provision of citizens with basic human needs and, at the same time, as the risk of loss of a significant part of assets by the country as a whole, and by individual households. After all, Global real estate assets comprise nearly $60 \%$ of the value of all global assets, including equities, bonds, and gold. Three-quarters of global real estate value is residential, $13 \%$ commercial and $12 \%$ agricultural. And the average cost of residential real estate households in the world is 43 thousand USD (Savills World Research, 2016).

In the problem of sustainable housing for citizens, the following issues are highlighted: financing the renovation of buildings, including apartment buildings. Studies by A. Babak (Nikolaiev, Babak, 2018), V. Nikolaev (Nikolaiev, Nikolaieva, 2014), and T. Nikolaeva (2016) are devoted to these issues.

Objectives of the article consist in deepening the formulation and methods of analysis of the achievement of SDG-11 regulations on housing, including solving the problem of sustainable housing on the basis of public-private partnership and projectoriented approach to evaluating investment projects for compliance with SDG.

\section{Problems of sustainable housing for citizens}

The results of the analysis of the sustainability of housing in Ukraine indicate the following:

- volumes of housing renovation due to the introduction of new housing about 10 million sq.m per year, which are determined by the solvency of up to $10 \%$ of citizens (Pinda, 2018), are insufficient for renovation;

- high wear and tear of houses and insufficient total renovations accelerate the disposal of housing. Thus, total renovations are needed in old houses and massproduced buildings of 1960-1980, which make up about $80 \%$ of the area of apartment buildings. On the other hand, the percentage of households that suffer from excessive wear and tear is $64.9 \%$ (Kucherenko, 2019);

- in terms of transferring the cost of total renovations to apartment owners, the share of the population that is financially unable to purchase or overhaul (reproduce) their own housing in apartment buildings will also be up to $80 \%$ (Shcherbina, 2019);

Solving these financial problems is extremely important for Ukraine, where ownership of residential real estate of high but not formally defined value dominates. With 17 million households, the total value of the residential real estate at a global average of 43 thousand USD (Savills World Research, 2016) could amount to 731 billion USD, or more than 20 trillion $\mathrm{UAH}$. This is absurdly combined with:

- receivables from the population for housing and communal services, which, according to official data at the end of May 2020, amounted to 59.9 billion UAH, including for the supply and distribution of natural gas - 23.9 billion UAH, for the supply of thermal energy and hot water -18.8 billion UAH, for the supply and distribution of electricity - 5.8 billion UAH, for centralized water supply and sewerage -5.4 billion $\mathrm{UAH}$, for the management of an apartment building 5.0 billion UAH, for the removal of household waste 1.0 billion UAH;

- the long-term needs in the overhaul of buildings, estimated at at least 600 to 2400 billion UAH, depending on the level of modernization (Nikolaiev, Kucherenko, 2019);

- the provision of housing and communal benefits and subsidies to the population in the amount of UAH 47.5 billion by the state in 2019 ( 71 billion UAH in 2018).

Therefore, own housing after the expiration of the service life for most owners will disappear in our conditions. Therefore, there is no alternative to creating other homeownership systems, where sustainable reproduction of the housing stock is possible.

Through redistribution mechanisms, the state should actively participate in the regulation and financing of housing because, according to Article 47 of the Constitution of Ukraine, "citizens in need of social protection are provided with housing by the state and local governments free of charge or for a fee under the law", which is impossible while maintaining the existing property relations and will be completely unrealistic after the decommissioning of a significant number of housing facilities (Constitution of Ukraine, 1996).

Reforming property relations in the housing sector in order to form an efficient owner and in accordance with the goals of sustainable development should be based on such principles as:

- ensuring the efficiency of property objects - buildings (their design, construction, operation), prevention of premature destruction;

- ensuring the efficiency of the whole set of households, their economic behavior, including awareness of financial capacity or inability to maintain, operate facilities;

- ensuring management efficiency, the formation of the efficient organizational forms and management structures, use of modern methods and information resources;

- ensuring an efficient institutional environment for market relations in the housing sector and state support for people on lower incomes.

This requires a revision of the state housing policy in the direction of ensuring both the processes of reproduction in the housing sector and guarantees of housing for those who are unable to purchase and maintain it at their own expense.

The full cost of owning and using housing must be reasoned. Nowadays, the average Ukrainian family pays about $8 \%$ of the cost of all housing services for the 
maintenance of buildings and structures and adjacent territories (housing services) without taking into account the cost of total renovation and the purchase of housing. In the EU countries, statistical housing costs include, in addition to current maintenance, the cost of total renovation and the purchase of new apartments and houses, taking into account more than $70 \%$ of the cost of all housing services (Panteleev, 2018).

Depending on the quality and cost of housing, the ownership relations and structure of the existing multistoreyed apartment housing stock should be diversified: the social housing stock is formed, the income houses are widespread. Individual housing construction will develop in parallel. For the transformation of property rights (transition of apartments to the category of social housing and tenement houses), in addition to buying and selling, new financial mechanisms common in the West must be introduced: reverse mortgage and distributed loan. Additional funds of state and local budgets on programs for the preservation and renovation of housing, in particular, social housing, can be obtained as a result of reforming taxes and fees in construction, real estate, and land, possibly when the introduction of housing tax, balanced with the needs of relevant state and local housing programs.

In many countries, the construction of social housing is an important component of public housing policy. The development of the social housing sector should become an important area of state housing policy in Ukraine. In our opinion, it is necessary to ensure the development and implementation of the State Program for the Creation of the Social Housing Sector in Ukraine. Such a program should provide for a gradual (over 10 years) increase in the share of social housing to $30-50 \%$ of the total living space in apartment buildings in need of repair (albeit up to 200 million sq. m). The estimated amount of funds required for the implementation of the program through a total renovation, modernization, and reconstruction of existing buildings at a unit cost of 25,000 UAH per 1 sq. $\mathrm{m}$, amount to 50 billion UAH annually.

\section{The role of local self-government (LSG) strategies}

Organizationally, ensuring the achievement of SDG-11 is most related to regional governance (Shevchenko et al., 2020), the competencies of LSG, which is responsible for ensuring balanced economic and social development of the territory (Nikolaiev et al., 2015).

Having broad powers provided by law (On local self-government in Ukraine, 1997), LSG in Ukraine can comprehensively contribute to the achievement of SDG-11 through the following measures: consideration of plans for the use of natural resources of local importance in the territory; making proposals to the programs of socio-economic development of districts and regions, respectively, as well as to the plans of utilities; establishing the procedure for the use of funds and other property; participation in the organization and financing of total renovations; registration of citizens who need to improve living conditions under the law; distribution and provision of residential and non-residential premises of communal property; assistance in the expansion of housing construction, obtaining mortgage loans; improvement of settlements; approval of sanitary cleaning schemes for settlements and introduction of systems of separate collection of household waste; performing the functions of the customer for the construction, reconstruction, and renovation of housing, other objects of the social and industrial infrastructure of communal property; making proposals to plans and programs for construction and reconstruction of facilities in the relevant area; preparation of local town-planning programs, general plans to build the settlements, other town-planning documentation; establishing the regime of land use and development; conducting a public discussion of urban planning documentation; control over ensuring the reliability and safety of buildings and structures.

Therefore, the above proposals for the transformation of approaches to the formation and implementation of public housing policy on the basis of sustainable development should be included in the tasks of SDG11. However, the powers defined in the law are not enough, it is important to realize who uses them and in what way. This is determined by state, local, and sectoral development strategies and programs, and in practice, it affects which investment projects are selected for funding from the state and local budgets (Maksiuta, Kovalivska, Pisheyko, Zhalilo, 2019). As Zhalilo and Kovalivska (2020) recognize that "agenda implementation not only joins the local level stakeholders, but also can form the landmarks to determine priority directions and targeted indicators in the strategic planning of development and gives an opportunity to reach the synergy of spatial development at the levels of region and country as a whole".

We should note that in the study (Sachs J. et al., 2020), Ukraine was in the group of countries with critically inefficient government strategies and policies to contain global warming, and these were comprehensive strategies that cover economic and environmental SDGs, including the tasks provided for in SDG-11.

Sustainable development cooperation seeks to adapt to a dynamic world and faces a growing need for strategies, adaptive and responsive to rapid change and high uncertainty. However, traditional approaches to linear planning based on historical data may have limited use in rapidly changing conditions. The SDG system is able to serve as a benchmark for setting priorities and targets in the process of strategic development planning at all levels - national, regional, and local, - which can become the basis for building partnerships at the vertical and 
horizontal levels in the public administration system, as well as in the formation of business strategies and their own life strategic guidelines of community members.

The value of a strategic approach based on the concept of sustainable development (SDG planning), taking into account aspects of the interaction of decisions to achieve specific goals and all goals in the complex, is to create sustainable sources of income from the responsible use of local natural, economic, human, and social potential, attracting investment resources, and, accordingly, the formation of expenditures that contribute to the development of the local economy, environmental protection, and social capital development, will create a basis for sustainable development of regions and communities and, accordingly, achieve SDG at the national level (Zhalilo, Bazyliuk, Kolomiets, Kovalivska et al., 2020).

The approach to achieving SDG should be multifaceted and require the implementation of an agreed set of measures in the exercise of its own and delegated powers in accordance with applicable law, taking into account the national objectives set out in the National Report "Sustainable Development Goals: Ukraine" (The Ministry of Economic Development and Trade of Ukraine, 2017). The approach complexity involves the assessment of any investment projects in terms of their impact on the achievement of several SDGs, and vice versa - how the tasks of other SDGs will affect the achievement of the studied project using the following methods of selection of investment projects for budget support and development of recommendations for their implementation taking into account the SDG (proposed by S. Kovalivska, the author).

This requires the introduction of measures and strengthening the capacity of public authorities and local governments to determine the priorities of communities and territories in achieving national goals based on the common characteristics in the social, economic, environmental spheres, i.e. defining of SDG-identity of communities, which should be the basis for SDG-planning and SDG-strategizing of communities, and will become the basis for the creation of the partnership, cooperation between different administrative territorial units on the basis of defined priorities, by:

- wide dissemination of information about SDG;

- development and approval of methodological recommendations for taking into account the sustainable development goals and objectives in community development strategies, sectoral programs;

- improving the procedures for budget planning and reporting on the implementation of SDG in the budget process at the state and local levels, based on the proposed approach to the selection of investment projects taking into account SDG-identity of the projects;

- development of an online training program for public authorities and local governments, which would include the implementation of practical tasks related to the current tasks in the field of strategic planning for sustainable development, and the introduction of the obligation to participate in this training.

The practice of financing housing projects in the absence of investment justifications. In the conditions of insufficient solvency of owners/residents, which does not allow them to fulfill their responsibilities for proper maintenance of houses and purchase of housing in the strategic perspective, local governments were forced to decide on tenders for energy-efficient projects, which are implemented on co-financing terms (70/30) (On approval of the call for proposals for the implementation of energy efficiency measures in homes of Kyiv, which created condominium associations, as well as cooperative, 2014), aimed at improving the technical condition of the housing stock through reconstruction, restoration, carrying out total renovation, technical re-equipment of common property in an apartment building.

Thus, in Kyiv, the decision of the Kyiv City Council approved the regulations on the competition of projects for residential buildings in the city of Kyiv, in which associations of co-owners of apartment buildings and cooperatives were established. If in 2015, 16 participants took part in the project in Kyiv, in 2018 119 participants, and in 2019 - 168 participants, who were given the opportunity to implement their energyefficient projects on a competitive basis. From 2015 to 2019, 238 million UAH was allocated for co-financing the energy modernization of the housing stock, and homeowners, for their part, invested 122.7 million UAH in only 333 houses. In 2016, according to the decision of the Kyiv City Council (On approval of the co-financing of the reconstruction, restoration, overhaul, technical re-equipment of common property in apartment buildings in Kyiv, 2016) in order to ensure co-financing of total renovations, residents of all homes were allowed to participate in projects.

If we consider the housing stock in terms of the city of Kyiv, today we can see the following picture: in total in Kyiv, there are 11,740 houses with a total area of $85,561.5$ thousand sq.m. Among them, there are 8368 houses serviced by municipal management companies, 892 HCCs, 759 condominiums, departmental residential buildings - 414 houses, 931 investment houses, 376 dormitories. Less than 5-storey houses - 2307, 5-storey houses - 3254, 6-10 storey houses - 3494, more than 10-storey houses -2685 .

In the absence of any methods of project selection for the implementation of local programs of thermal modernization of the housing stock, a method of approach is proposed, according to which up to 5-storey houses will be to participate in the competition on the terms of co-financing 70/30; 5 -storey houses - 75/25; 6 - 10 storey houses $-80 / 20,10$-storey houses $-85 / 15$. This is due to a number of factors, such as the cost of 
thermal modernization, work completion time, the work technical complexity.

However, co-financing programs need deeper justifications in the methodology for the creation and implementation of economic and environmental projects.

The general approach, taking into account the age and condition of the houses can look like this:

Houses built before 1970: state budget - 60\%, local budget $-25 \%$, homeowners - $15 \%$. Houses built before 1980: $55 \%, 20 \%$, and 25\%. Houses built before 1980:50\%, 25\%, 25\% respectively (Popenko, 2020).

On June 8, 2017, the Law "On the Energy Efficiency Fund" (2017) was adopted, and therefore the financing of payments from the state budget could go through the Energy Efficiency Fund with the involvement of donor funds.

The application of an integrated approach in the formation of the model of public-private partnership of co-financing of total renovations, taking into account SDG-11, will help to improve the housing stock, as well as environmental protection and social capital development.

\section{Investing in sustainable development projects}

Taking into consideration all the aforementioned, the selection of investment projects for budget support and development of recommendations for their implementation taking into account SDG is proposed to apply taking into account conceptual approaches to assessing the efficiency of projects in the public sector for their further selection using an integrated rating and weight system for evaluating investment projects.

To this end, a method for assessing the impact of the project on achieving the Sustainable Project Assessment of Ukraine and tools in MS Excel for calculations, including a matrix of interactions of project objectives on SDG, and SDG to achieve project objectives, as well as forms for filling evaluation results.

Here are the main stages of the methodology for selecting investment projects for budget support and development of recommendations for their implementation, taking into account SDG.

1. Selection of projects for budget support.

In the beginning, it is planned to carry out an economic analysis of the project, which includes the analysis of benefits and costs in terms of its social efficiency in order to determine the feasibility of the project and choose the most efficient way to implement it. It is advisable to apply the recommendations on the stages and methodology of cost-benefit analysis (Rozputenko, Bazhal, Kilievich \& Martens, 2002). A project will be eligible if the aggregate benefits of its implementation, calculated on the basis of certain values of the value of all its consequences, exceed the corresponding aggregate costs, as well as it meets the following criteria:

a) it has positive socio-economic results;

b) it corresponds to operational support programs, development priorities, and other areas provided for in development strategies. This is achieved by verifying that the benefits of the product produced by the project are related to program (strategic) goals;

c) it needs budget funding.

2. Assessment of the project's impact on sustainable development goals.

To do this, it is proposed to fill in results of the calculations in the matrix of mutual influences of project objectives on SDG, and SDG to achieve project objectives (horizontally and vertically placed first project objectives, then goals and objectives of sustainable development, localized for the appropriate level (national, regional, local)), at the intersection in matrix cells, according to the following principle:

- to assess the impact of each SDG horizontally according to each project goal vertically with a mark in the cell at the intersection of the degree of impact of tasks on a scale: -2 - "significantly negative", -1 - "insignificantly negative", 0 - "absent", +1 - "insignificantly positive", +2 - "significantly positive";

- to assess the impact of each project objective vertically on each SDG horizontally with a mark in the cell at the intersection of the degree of impact of tasks on a scale: -2 - "significantly negative", -1 - "insignificantly negative", 0 - "absent", +1 - "insignificantly positive", +2 - "significantly positive";

- to determine the sum of estimates for each goal horizontally and vertically and find the maximum and minimum values of the sum of estimates vertically and horizontally, which mean, respectively, indicators: MAX values of the project's impact on SDG; MIN value of the project impact on SDG; MAX value of SDG impact on the project; MIN value of SDG impact on the project.

It is further proposed to develop recommendations to support the implementation of the project in accordance with SDG using and completing the SWOT + Sustainability Project Assessment (SPA) tool (Table 2).

All researched projects should be ranked from the maximum to the minimum value for each goal in order to determine the rating of the project with the so-called achievement of SDG (SDG-identity of the project). It is also proposed to use weights for each SDG, taking into account the provisions of the community strategy (SDG-strategizing).

3. Determining the amount and type of budget support.

The input parameters for the analysis should be the assessment of budget support based on coefficients that take into account the maximum possible percentage of state financial (share) support for the project, adjusted 
Table 2

SWOT+Sustainability Project Assessment (SPA)

\begin{tabular}{|c|c|c|}
\hline Impact of the project on SDG & Positive Impact & Negative impact \\
\hline SDG Impact on the Project & $\begin{array}{c}\text { Promotes sustainable development } \\
\text { (MAX project impact on SDG, goal title) }\end{array}$ & $\begin{array}{c}\text { Inhibits sustainable development } \\
\text { (MIN project impact on SDG, goal title) }\end{array}$ \\
\hline $\begin{array}{c}\text { Opportunities (MAX value of SDG impact } \\
\text { on the project, goal title) }\end{array}$ & $\begin{array}{c}\text { Threats (MIN value of SDG impact } \\
\text { on the project, goal title) }\end{array}$ \\
\hline
\end{tabular}

to the level of manufacturability, and export orientation (Maksiuta, Avramchenko, Deshko, Fedchishyn, Kovalivska, Onufryk, Zhalilo, 2016), and SDG-identity (rating) of the investment project. That is, the higher these ratios, the greater the share of state support that an investment project can potentially receive.

In order to optimize budget resources and implement an efficient state support policy, it is advisable to conduct a comprehensive analysis of commercial, budgetary, and social efficiency of investments at this stage.

As a result, 3 main parameters are compared: commercial efficiency, budget efficiency, social efficiency.

Possible combinations of positive and negative values of these indicators will give eight arrays of possible variants of efficiency values for decision-making or adjustment of the type and share of state support of the project. The alternative should be to reduce the share of state support, any other type of state aid (rules and relevant institutions providing such support should be fully proposed).

Regarding budget planning, it is recommended to ensure the transition to results-oriented funding. Budget allocations must be sufficient to achieve the planned results, and each state target program or plan for implementing a program or strategy must clearly link each task to the relevant budget program. Due to the improvement of coding, budget programs should be further classified by SDG. In such a system, the total amount of funding for tasks under all program documents should be equal to the amount of funding for tasks in all budget programs of the year (Maksiuta, et al., 2017). Thus, it would be possible to assess the contribution of public funds to the achievement of SDG and assess the efficiency of the decision to change policy in relevant areas. This should pave the way for achieving the objectives of the relevant policies. At the same time, the discipline of mandatory financing of planned activities should be an integral prerequisite for achieving SDG in order to improve the effectiveness and efficiency of the strategic planning process in Ukraine.

The objectives and targets of the SDG indicators can be coordinated at the planning stage, taking into account budgetary constraints and the priority areas of government programs.

4. Development of recommendations based on SWOT+SPA.

For each of the selected projects, it is proposed to develop recommendations using the proposed forms (Table 3) and an action plan to support project implementation in accordance with SDG (Table 4).

\section{Conclusions}

In Ukraine, there are negative trends in the dynamics of indicators that measure the achievements of SDG11 "Make cities and human settlements inclusive, safe, resilient and sustainable", both on indicators at the global and national levels. At the same time, there are differences in indicators at the global and national levels, which indicates that the situation in Ukraine is not monitored with the consistency of domestic statistics with international ones.

The low attention to the impact of the construction sector, in particular, the state of the housing stock

Table 3

Recommendation matrix based on SWOT + SPA

\begin{tabular}{|l|l|l|l|}
\hline \multicolumn{1}{|c|}{ Indicator } & $\begin{array}{c}\text { Quantitative } \\
\text { assessment, points }\end{array}$ & $\begin{array}{l}\text { Title of SDG of the } \\
\text { respective indicator }\end{array}$ & $\begin{array}{c}\text { Recommendations for project management } \\
\text { taking into account the results }\end{array}$ \\
\hline 1. MAX value of the project impact on SDG & & $\begin{array}{l}\text { Grant opportunities, } \\
\text { Information campaign, } \\
\text { Partnership opportunities }\end{array}$ \\
\hline 2. MIN value of the project impact on SDG & & $\begin{array}{l}\text { Grant opportunities, } \\
\text { Mitigation strategy }\end{array}$ \\
\hline $\begin{array}{l}\text { 3. MAX value of the SDG impact on the } \\
\text { project }\end{array}$ & & $\begin{array}{l}\text { Consideration and revision of the project plan } \\
\text { and resources, } \\
\text { Partnership opportunities }\end{array}$ \\
\hline $\begin{array}{l}\text { 4. MIN value of the SDG impact on the } \\
\text { project }\end{array}$ & $\begin{array}{l}\text { Consideration and revision of the project plan } \\
\text { and resources, } \\
\text { Risk management strategy }\end{array}$ \\
\hline
\end{tabular}


Table 4

Action plan to support the implementation of the project in accordance with SDG

\begin{tabular}{|c|c|}
\hline $\begin{array}{l}\text { Recommendations } \\
\text { (from Table 3) }\end{array}$ & Priority measures (standard proposals for investment projects in construction are given) \\
\hline Grant opportunities & $\begin{array}{l}\text { For projects with maximum impact on SDG, the following is recommended: } \\
\text { - list of organizations and banks providing financing (non-refundable financing is possible) } \\
\text { - list of state and municipal programs that provide for co-financing of construction projects depending } \\
\text { on the type of project ( } 70 / 30 \text {, housing for ATO veterans, subventions from the state budget to local } \\
\text { infrastructure, SFRD revolving funds, etc.) } \\
\text { - list of loan reduction programs; } \\
\text { For projects with minimal impact on SDG: } \\
\text { - list of organizations and banks that provide loans for construction, including mortgage } \\
\text { Recommendations for reviewing the project with the so-called ensuring a positive impact on SDG }\end{array}$ \\
\hline Information campaign & $\begin{array}{l}\text { The list of current programs of information campaigns of local and state authorities, which will include } \\
\text { measures to inform the public about this project, its positive effects on the achievement of SDG, is } \\
\text { presented, in particular: SDG-11, to ensure access to housing, reducing emissions from stationary } \\
\text { sources, and other goals that characterize energy efficiency, resource intensity, waste management, } \\
\text { sewerage, and water supply. }\end{array}$ \\
\hline Partnership opportunities & $\begin{array}{l}\text { The conditions under which the local authorities are ready to consider the project within the framework } \\
\text { of public-private partnership under current legislation are provided. Opportunities for social housing } \\
\text { programs for people in need of social protection }\end{array}$ \\
\hline Mitigation strategy & $\begin{array}{l}\text { For projects with minimal impact on SDG: } \\
\text { Review of the construction project from the viewpoint of } \\
\text { - environmental impact assessment of the project: } \\
\text { - creation of additional supporting infrastructure to promote the sustainability of cities, } \\
\text { - creating infrastructure sustainability; } \\
\text { - supplementing the project with anti-epidemic resilience analysis; } \\
\text { - taking into account the needs of people with disabilities; } \\
\text { The list of consulting organizations to review the project with the so-called ensuring a positive impact on SDG }\end{array}$ \\
\hline Risk management strategy & $\begin{array}{l}\text { To improve the project risk management strategy from the viewpoint of the increase of the probability of } \\
\text { negative impact of SDG on the project. For example, non-compliance with SDG-13 to reduce emissions } \\
\text { may result in a sharp rise in temperature in cities, for which the project should provide appropriate } \\
\text { safeguards: the creation of park areas, cooling, blackouts, and so on. The proximity of the construction site } \\
\text { to the coastal zones should take into account the possibilities to avoid flooding given the likelihood of sea } \\
\text { level rise. It is necessary to assess the impact of the probability of failure of each SDG on the project and } \\
\text { to propose measures and appropriate adjustments to the project if there is a close link with the objectives } \\
\text { and a high probability of risk. }\end{array}$ \\
\hline $\begin{array}{l}\text { Consideration and revision of } \\
\text { the project plan and resources }\end{array}$ & $\begin{array}{l}\text { Review of the construction project from the viewpoint of the assessment of all building components for } \\
\text { the possibility of their replacement by those that: } \\
\text { - provide better energy efficiency; } \\
\text { - are made from processed raw materials; } \\
\text { - have lower resource intensity; } \\
\text { - have lower emissions / pollution rates; } \\
\text { - reducing the cost of operational characteristics of a promising facility through the introduction of } \\
\text { energy-saving and other innovative technologies, comparative characteristics of the improved project } \\
\text { with the typical (previous) from the viewpoint of the impact on the environment and social living } \\
\text { conditions; }\end{array}$ \\
\hline
\end{tabular}

on SDG and, conversely, the achievement or failure of SDG in the housing sector (SDG-11) in general requires an in-depth analysis of its role and place in the 2030 Agenda and development of appropriate recommendations.

The main problem that hinders the achievement of SDG-11 is the lack of effective mechanisms for financing the renovation of buildings, including apartment buildings.

Given the state of wear and tear of the housing stock, the scale of the problem, and the very high cost of its renovation, it is impossible to solve the problem only at the expense of homeowners, therefore, without changing public policy in housing to achieve SDG11 interconnected, are in a zone of high risk, because after the end of service own housing for most owners will disappear, which will certainly worsen the indicators of poverty, inequality, negative impact on the environment.

To reform property relations in the housing sector in Ukraine, it is proposed to create mechanisms for the formation of an effective owner, in particular: 
the property itself, the whole set of households, management, operation, and institutional environment. Among the results of such a policy, there is a significant expansion of the social housing stock, the expansion of apartment buildings, repayable mortgages and distributed loans, housing preservation and renewal programs, the creation of revolving funds for total renovations, and the introduction of a housing tax.

Based on the analysis of the competence of local selfgovernment bodies, it was determined that the greatest extent to ensure the achievement of SDG-11 is related to regional and local government. Regarding weakness of strategic management at this level, which does not allow to address the issue of housing renovation: strategic planning at the local level is proposed, it is identified as a basis for building partnerships at the vertical and horizontal levels in the public administration system. In this case, the complexity of SDG, which should be presented in the strategies, should be selected in the projects that are planned for their implementation.

In the absence of opportunities for total renovation by co-owners of apartment buildings, state and municipal housing modernization programs come to the fore, which do not prescribe clear criteria for co-financing conditions for different types of buildings and different types of age.
In our opinion, the existing programs require a systematic approach to the definition of appropriate mechanisms of public administration at both state and regional levels, which will allow to consolidate the budgets at all levels, to address large-scale housing problems covering almost all sectors of the economy and social life.

Given the current circumstances, at the level of economic entities: condominiums, housing, and communal services, municipal and private management companies, as well as local governments, require immediate resolution of economic, energy and technical assessment of facilities, identification and communication to co-owners houses of financial needs for their maintenance taking into account necessary total renovation. As a tool for the implementation of such an integrated approach, a methodology for selecting investment projects for budget support and development of recommendations for their implementation, taking into account SDG, has been developed and presented, and approaches for its application in the construction sector are presented. This technique will achieve significant results in improving the technical condition of the housing stock and the rapid achievement of sustainable development goals.

\section{References:}

Belenkova, O. (2020). Imperatyvy staloho rozvytku v systemi zabezpechennia stratehichnoi konkurentospromozhnosti budivelnykh pidpryiemstv: teoriia, metodolohiia, praktyka [Imperatives of sustainable development in the system of ensuring the strategic competitiveness of construction enterprises: theory, methodology, practice]. (Dr.Sci. in Econ. Thesis, Ukraine). Kyiv. (in Ukrainian)

Konstytutsiia Ukrainy [Constitution of Ukraine] (1996). Basic Law of Ukraine, adopted on 1996, Jun 28, 254K/96-VR. Kyiv: Supreme Council of Ukraine. Legislation of Ukraine. Available at: https://zakon.rada.gov.ua/ laws/show/254\%D0\%BA/96-\%D0\%B2\%D1\%80\#Text (in Ukrainian)

Kucherenko, O. Yu. (2019). Stratehii i rezultaty derzhavnoi zhytlovoi polityky v Ukraini [Strategies and results of the state housing policy in Ukraine]. Vcheni zapysky Tavriiskoho natsionalnoho universytetu imeni V. I. Vernadskoho. Seriia: Derzhavne upravlinnia - Scientific notes of Tavriya National University named after V. I. Vernadsky. Series: Public Administration, vol. 30(69), no. 3, pp. 109-118. Available at: http://www.pubadm.vernadskyjournals.in.ua/ journals/2019/3 2019/21.pdf

Kuybida, V. S., Nikolaiev, V. P. (Eds), Nikolaieva, T. V., Sichny, S. B. \& others (2018). Budivelne informatsiine modeliuvannia $v$ upravlinni vartistiu zhyttievoho tsyklu obiektiv [Education and information model in the management of the life cycle of enterprises]. Ivano-Frankivsk. Yarina. (in Ukrainian)

Kuybida, V. S., Nikolaiev, V. P., \& Nikolaieva, T. V. (2017). Menedzhment obiektiv nerukhomosti publichnoi vlasnosti [Management of public real estate]. Kyiv: NAPA. (in Ukrainian)

Maksiuta, A. (Eds), Kovalivska, S., Nikolaiev, V., \& others (2017) Implementing the 2030 Sustainable Development Goals in Ukraine: analysis of government strategies and public policy: Executive Summary of the Analytical Study. Kyiv: Institute for Social and Economic Research. Available at: https://www.ua.undp.org/content/ukraine/uk/ home/library/sustainable-development-report/sdg-goals-ua-govt-strategies-full.html

Maksiuta, A. (Eds), Avramchenko, K. V., Deshko, A. L., Fedchishyn, Yu. A., Kovalivska, S. V., Onufryk, M. S. \& Zhalilo, Ya. A. (2016). The policy of economic pragmatism. Kyiv: The Institute for Social \& Economic Studies. Available at: https://iser.org.ua/uploads/pdf/NEP big_ENG_NEW_2 print.pdf

Maksiuta, A. (Eds), Kovalivska, S. V., Pisheyko, V. $\bar{O} .$, \& Zhalilo, Ya. A. (2019). Vymiriuvannia dosiahnennia tsilei staloho rozvytku rehionamy Ukrainy: vybir indykatoriv ta vyznachennia bazovykh rivniv [Measuring the achievement of sustainable development goals by the regions of Ukraine: the choice of indicators and the definition of baseline levels]. Kyiv. Available at: https:/9www.ua.undp.org/content/ukraine/uk/home/library/sustainabledevelopment-report/tracking-progress-on-SDGs-for-the-regions-of-Ukraine.html

Nikolaiev, V. P. (Eds.), \& others. (2015). Finansuvannia rehionalnoho rozvytku: stratehiia $i$ metody [Financing regional development: strategy and methods]. Irpin: USFSU. (in Ukrainian) 
Nikolaiev, V. P., \& Babak, A. V. (2018). Formuvannya sehmentu vlasnoho zhytla meshkantsiv bahatokvartyrnykh budynkiv i novi zadachi upravlinnya [Formation of the segment of own housing of apartment building residents and new management tasks]. Shliakhy pidvyshchennia efektyvnosti budivnytstva $v$ umovakh formuvanna rynkovykh vidnosyn - Ways to increase the efficiency of construction in the formation of market relations, vol. 37, pp. 127-137. (in Ukrainian)

Nikolaiev, V. P., \& Nikolaieva, T. V. (2014) Ekoloho-ekonomycheskaya effektyvnost zdanyy y novye ynformatsyonnye tekhnolohyy [Ecological and economic efficiency of buildings and new information technologies]. Pryrodokorystuvannya i stalyy rozvytok: ekonomika, ekolohiya $i$ upravlinnya - Nature management and sustainable development: economics, ecology and management. Irpin: USFSU. (in Ukrainian)

Nikolaieva, T. V. (2016). Analiz zhyttievoho tsyklu yak metodolohichna osnova ekonomiko-ekolohichnykh obhruntuvan [Life cycle analysis as a methodological basis of economic and environmental justifications]. Ekolohichni vyklyky i staly rozvytok: ekonomichni, pravovi ta ekolohichni aspekty - Environmental challenges and sustainable development: economic, legal and environmental aspects. Kyiv: Format. (in Ukrainian)

Nikolaieva, T. V. (2018). Vartisno-oriientovane upravlinnia nerukhomym mainom derzhavnoi vlasnosti [Cost-oriented management of state-owned real estate]. Irpin: USFSU. (in Ukrainian)

Nikolaiev, V., \& Kucherenko, O. (2019). Prevention of housing stock collapse in Ukraine requires extraordinary strategic decisions. In 26th Annual European Real Estate Society Conference. ERES: Cergy-Pontoise, France. Available at: https://eres.architexturez.net/system/files/P_20190822113136_7823.pdf

Panteleiev, P. O. (2018). Otsiniuvannia stanu i vartosti utrymannia zhytlovykh budynkiv budivelnoekspluatatsiinymy pidpryiemstvamy [Assessment of the condition and cost of maintenance of residential buildings by construction and maintenance companies]. (Ph.D. in Econ. Thesis, Kyiv National University of Construction and Architecture, Ukraine). Kyiv. (in Ukrainian)

Pinda, Yu. V. (2018). Stratehiia rozvytku budivelnoho sektoru Ukrainy [Strategy of development of the construction sector of Ukraine]. Lviv: Rastr-7. (in Ukrainian)

Popenko, O. I. (2020). Publichno-pryvatne partnerstvo spivfinansuvannia termomodernizatsii zhytlovoho fondu na rehionalnomu rivni [Public-private partnership of co-financing of thermal modernization of housing stock at the regional level]. Pravo ta derzhavne upravlinnya - Law and public administration, vol. 1, pp. 166-169. Available at: http://www.pdu-journal.kpu.zp.ua/archive/1_2020/tom_2/26.pdf

Pro fond enerhoefektyvnosti [On the energy efficiency fund] (2017). Law of Ukraine, adopted on 2017, Jun,8, 2095-VIII. Kyiv: Supreme Council of Ukraine. Legislation of Ukraine: Website. Available at: https://zakon.rada.gov.ua/laws/show/2095-19

Pro mistseve samovryaduvannia v Ukraini [On local self-government in Ukraine] (1997). Law of Ukraine, adopted on 1997, May 21, 280/97-VR. Kyiv: Supreme Council of Ukraine. Legislation of Ukraine: Website. Available at: https://zakon.rada.gov.ua/laws/show/280/97-\%D0\%B2\%D1\%80\#Text

Pro zatverdzhennia Polozhennia pro konkurs proektiv z realizatsiyi enerhoefektyvnykh zakhodiv u zhytlovykh budynkakh mista Kyyeva, v yakykh stvoreni ob'yednannya spivvlasnykiv bahatokvartyrnykh budynkiv, a takozh $\mathrm{u}$ kooperatyvnykh budynkakh [On approval of the call for proposals for the implementation of energy efficiency measures in homes of Kyiv, which created condominium associations, as well as cooperative] (2014). The decision, adopted on 2014, Dec 26, 865/865. Kyiv: the Kyiv City Council. Rule-making activity. Available at: http://kmr.ligazakon.ua/SITE2/1_docki2.nsf/alldocWWW/5F3F8A90084D6E86C2257DD9006DF0CE? OpenDocument

Pro zatverdzhennia Polozhennia pro spivfinansuvannya rekonstruktsii, restavratsii, provedennia kapitalnykh remontiv, tekhnichnoho pereosnashchennia spilnoho maina u bahatokvartyrnykh budynkakh mista Kyieva [On approval of the co-financing of the reconstruction, restoration, overhaul, technical re-equipment of common property in apartment buildings in Kyiv] (2016). The decision, adopted on 2016, Dec 22, $780 / 1784$. Kyiv: the Kyiv City Council. Rule-making activity. Available at: http://kmr.ligazakon.ua/SITE2/1_docki2.nsf/ alldocWWW/78805654CC396F16C225809F006DF7A8?OpenDocument

Rozputenko, I. (Esd), Bazhal, Yu., Kilievich, O. \& Martens, A. (2002). Efektyvnist derzhavnoho upravlinnia [Efficiency of public administration]. Kyiv: K.I.S. (in Ukrainian)

Sachs, J., Fuller, G., Kroll, C., Lafortune, G., Schmidt-Traub, G., \& Woelm, F. (2020). The Sustainable Development Goals and COVID-19. Sustainable Development Report 2020. Cambridge: Cambridge University Press. Available at: https://s3.amazonaws.com/sustainabledevelopment.report/2020/2020_sustainable_development_ report.pdf

Savills World Research (2016). Around the world in dollars and cents. What price the world? Trends in international real estate trading: Author. Available at: https://pdf.euro.savills.co.uk/global-research/around-the-world-in-dollarsand-cents-2016.pdf

Shcherbyna, A. A. (2019). Balansova model rozvytku rynku zhytlovo-komunalnykh posluh $z$ urakhuvannyam platospromozhnosti spozhyvachiv [Balance model of development of the market of housing and communal services taking into account solvency of consumers]. (Ph.D. in Econ. Thesis, Kharkiv National University of Municipal Economy named after OM Beketova, Ukraine). Kharkiv. (in Ukrainian)

Shevchenko, O. V., Romanova, V. V., \& Zhalilo, Ya. A. (Eds.) and others. (2020). Detsentralizatsiya i formuvannya polityky rehionalnoho rozvytku $v$ Ukrayini [Decentralization and formation of regional development policy in Ukraine]. Kyiv: NISS. (in Ukrainian) 
Shevchuk, V. (2006). Makroekonomichni problemy staloho rozvytku [Macroeconomic problems of sustainable development]. Kyiv: Geoprint. (in Ukrainian)

Shevchuk, V. Ya., Kovalchuk, T. T., Malisheva, N. R., \& Mantsurov I. I. (Eds.) (2014). Polityka enerhoefektyvnoho rozvytku $i$ zminy klimatu [Energy efficiency and climate change policy]. Kyiv: Comprint. (in Ukrainian)

Siniak, N. G., \& others (2015). Innovatsionnoye i ustoychivoye razvitiye rynkov nedvizhimosti [Innovative and sustainable development of real estate markets]. Minsk: BSTU. (in Russian)

State Statistics Service of Ukraine (2020). Statistical Information: Sustainable development goals. Available at: http://www.ukrstat.gov.ua/csr_prezent/engl/ukr4_EN/index.html

The Ministry of Economic Development and Trade of Ukraine (2017). Sustainable Development Goals: Ukraine. National report. Kyiv: Author. Available at: https://me.gov.ua/Documents/List?lang=uk-UA\&id=938d9df1-5e8d48cc-a007-be5bc60123b8\&tag=TSiliStalogoRozvitku

Voitov, I. V. (Eds) \& others (2018). Menedzhment obyektov nedvizhimosti: biznes-protsessy $i$ metody [Property management: business processes and methods]. Minsk: BSTU. (in Russian)

Zhalilo, Ya. A. (Eds), Bazyliuk, Ya. B., Kolomiets, O. O., Kovalivska, S. V., \& others (2020). Ukraina pislia koronakryzy - shliakh oduzhannya [Ukraine after the corona crisis is a way of recovery]. Kyiv: NISS. Available at: https://niss.gov.ua/sites/default/files/2020-11/ukraina-pislya-koronakrizi_sait.pdf

Zhalilo, Ya. A., \& Kovalivska, S. V. (2020). Realizatsiya tsiley staloho rozvytku yak pidgruntya intehratsiyi prostorovoho ta rehionalnoho rozvytku [Realization of sustainable development goals as a basis for integration of spatial and regional development]. Finansy Ukrainy - Finance of Ukraine, vol. 9, pp. 9-14. doi: https://doi.org/10.33763/finukr2020.09.009 (in Ukrainian) 